\title{
Morphological and physiological performance of PSB Rc18 lowland rice (Oryza sativa L.) grown at different water, spacing and nutrient management
}

\author{
Ruth O. Escasinas ${ }^{1 *}$ and Oscar B. Zamora ${ }^{2}$
}

\begin{abstract}
Rice yield fluctuates because of environmental influences on morphological and physiological processes, as well as inadequate human intervention, to stabilize crop productivity. A field experiment was conducted in two cropping seasons at the experimental area of the Department of Agronomy, Visayas State University, Baybay, Leyte to evaluate the morphological and physiological performance of lowland rice grown at different water, spacing and nutrient management. Different sources of fertilizers were designated as the mainplot and plant spacing as the subplot nested within two water regimes, ie, continuous flooding and no flooding.

Lowland rice plants under no flooding were shorter than those under continuous flooding. No flooding gave higher root pulling resistance, crop growth rate, net assimilation rate, leaf area index and harvest index and consequently produced higher grain yield of PSB Rc18. No flooding and continuous flooding water management resulted in the formation of aerenchyma cells in roots of rice plants which had statistically similar cell number and measurement. Wider spacing of $40 \mathrm{~cm} \times 40 \mathrm{~cm}$ gave the highest RPR. Water, spacing and nutrient management did not influence the phyllochron and total number of leaves on the main culm of PSB Rc18. However, PSB Rc18 at early growth stages tended to have longer phyllochron because of transplanting shock.

No flooding, application of composted goat manure and closer spacing of $20 \mathrm{~cm} \times 20 \mathrm{~cm}$ is the best treatment combination that gave similar yield to rice plants applied with inorganic fertilizer at the rate of $90-30-30 \mathrm{~kg} \mathrm{ha}^{-1} \mathrm{~N}, \mathrm{P}_{2} \mathrm{O}_{5}, \mathrm{~K}_{2} \mathrm{O}$.
\end{abstract}

Keywords: crop growth rate, harvest index, leaf area index, net assimilation rate, phyllochron, aerenchyma cells

\footnotetext{
'Department of Agronomy, Visayas State University, Baybay City Leyte 6521-A, Philippines

${ }^{2}$ Crop Science Cluster, University of the Philippines Los Baños, College Laguna 4031, Philippines
}

*Corresponding Author. Address: Department of Agronomy, Visayas State University, Baybay City Leyte 6521A, Philippines; Email: ruth.escasinas@vsu.edu.ph 
Morphological and physiological performance of PSB Rc18 lowland rice

\section{INTRODUCTION}

Rice is the main staple food of the Filipinos. The Philippines has made substantial progress in the production of rice in the last 40 years. Rice production grew at a rapid pace of $3 \%$ per annum in the last decade after a slowdown in the 1990s (DA 2012). The country's performance on rice production and yield growth compares favorably with the world's major rice producers. Despite increase in production growth, rice imports have gone up in the last decade due to growing population. Importations were also justified by bad harvest due to crop damage caused by prolonged drought and strong typhoons due to climate change. Thus, rice self-sufficiency in the country has been elusive.

There is a need to further boost rice production in order to meet the growing domestic demand and arrest the increasing reliance on imports. However, it is not easy to attain this target considering the decreasing fertility of rice farms, the prevalence of pests and diseases and the ever increasing cost of commercial inputs, including inorganic fertilizers and chemical pesticides. Thus, there is an urgent need for the innovation of affordable and environment-friendly rice production technologies, such as organic agriculture technologies that suit local conditions that can be easily adopted by farmers.

High and sustainable yield is the ultimate goal of any agricultural production system. However, yield fluctuates because of environmental influences on morphological and physiological processes, as well as inadequate human intervention to stabilize crop productivity. High rice grain yield is achievable only with proper combination of variety, environment and agronomic practices (Yoshida 1977). Cultural manipulations of the growth of a rice crop in organic production system include changing the spacing and spatial arrangement, recycling and use of organic fertilizer and alternative water management.

The rapid growth of population has resulted in significantly increased water demand. Worldwide, agriculture is the largest consumer of water, particularly the growing of rice. It is estimated that irrigated lowland rice receive some $34-43 \%$ of the total world's irrigation water, or $24-30 \%$ of the total world's freshwater withdrawals (Bouman et al 2007). With increasing water scarcity, the sustainability, food production and ecosystem services of rice fields are threatened. Therefore, there is a need to develop and disseminate water management practices that can help farmers to cope with water scarcity in irrigated environments (Bouman et al 2007).

Proper spacing results in better distribution of solar radiation and reduced phyllochron which consequently increase tillering, resulting in higher yield (Escasinas \& Zamora 2011). The use of organic fertilizer as alternative to chemical fertilizers would result in better soil structure and improved soil fertility. Recycling of animal wastes is an effective means of preventing environmental pollution due to use of synthetic inorganic fertilizers.

In the Philippines, several sustainable farming technologies are being adapted, including organic farming. Organic rice farming is location specific, ie, technologies that work in one region or other parts of the world may not be suitable under local conditions due to differences in agroecological and socioeconomic environments. Localized research is therefore essential for the development and establishment of management practices to enhance the productivity of lowland rice farming. 
This field experiment was conducted to evaluate the morphological, physiological and yield responses of lowland rice under different water, spacing and nutrient management.

\section{MATERIALS AND METHODS}

\section{Soil Sampling and Analysis}

Soil samples were collected randomly from the experimental area within depth of $0-20 \mathrm{~cm}$ before the conduct of the experiment. These samples were air dried and analyzed at the Soil Research Testing and Plant Analysis Laboratory, Department of Agronomy and Soil Science, Visayas State University (VSU), Baybay, Leyte for the determination of the following soil chemical characteristics: $\mathrm{pH}$ (potentiometric method), OM (Walkley-Black method), total N (Micro-Kjeldahl method) and extractable $\mathrm{P}$ (Bray \#2 method). The exchangeable $\mathrm{K}$ and cation exchange capacity (CEC) were analyzed at the Central Analytical Services Laboratory, PhilRootcrops Complex, VSU, Baybay, Leyte using the Ammonium acetate method. For final soil analysis, soil samples were randomly collected from each treatment plot after harvest.

\section{Time and Place and Design of the Study}

This study was conducted at the experimental area of the Department of Agronomy, VSU, Baybay, Leyte $\left(10^{\circ} \mathrm{N}\right.$ to $\left.124^{\circ} \mathrm{E}\right)$ during the wet season (November 2007 to February 2008) and dry season (April 2008 to July 2008).

The experiment was laid out in a nested design with complete blocks in three replications, with organic fertilizers as the mainplot (F1-Composted goat manure, 3t ha ${ }^{-1}$, F2-Compost mixture (Gliricidia sepium + goat manure + rice straw + carbonized rice hull, 1:1:1:1, 7t ha ${ }^{-1}$, F3-Inorganic fertilizer at 90-30-30kg NPK, F4Control, no fertilizer) and plant spacing $(S 1-20 \mathrm{~cm} \times 20 \mathrm{~cm}, 52-40 \mathrm{~cm} \times 10 \mathrm{~cm}$, S3$40 \mathrm{~cm} \times 40 \mathrm{~cm})$ as the subplot nested within two water regimes ie, continuous flooding (conventional) and no flooding or keeping the soil saturated but not flooded.

\section{Cultural Management Practices}

\section{Land preparation}

The area was plowed and harrowed twice (at weekly interval) using hand tractor. The field was leveled and levees were constructed to avoid possible movement or contamination of nutrients from one plot to another. Each block was surrounded by a canal for irrigation and drainage.

\section{Seedlings Preparation and Transplanting}

PSB Rc18 seeds were soaked in water for $24 \mathrm{~h}$ and then incubated for $36 \mathrm{~h}$. Pregerminated seeds were sown thinly and uniformly on raised seedbeds. Ten-day old seedlings were transplanted with one plant hill ${ }^{-1}$ in an East to West row orientation, 
Morphological and physiological performance of PSB Rc18 lowland rice

following the spacing specified in the treatment. Missing hills were replanted 3-4 days after transplanting.

\section{Fertilizer Application}

Goat manure, G. sepium, rice straw and carbonized rice hull of equal volume were composted for $21 / 2$ months before the start of the experiment. Goat manure and compost mixture were analyzed for NPK, $\mathrm{Zn}$ and $\mathrm{Cu}$ at the Central Analytical Services Laboratory, PhilRootcrops Complex, VSU, Baybay, Leyte. Composted goat manure and compost mixture were incorporated into the soil two weeks before planting. For inorganic fertilizer treatment $\left(F_{3}\right)$, the basal application was 60-30$30 \mathrm{~kg} \mathrm{ha}^{-1}$. The remaining $\mathrm{N}(30 \mathrm{~kg})$ was applied one month after planting.

\section{Water Management}

Water management was implemented as follows:

Continuous Flooding (Conventional, WM 1) - The field was continuously flooded up to $2 \mathrm{~cm}$ depth from three days after planting up to maximum tillering stage. Water level was increased to $5 \mathrm{~cm}$ at reproductive stage until 2 weeks before harvest.

No Flooding (WM 2) - The field was kept saturated by allowing entry of water but immediately drained to prevent flooding or submergence of the soil. Entry of water was allowed before the soil dried up or before it cracked.

\section{Pest Management}

A weed-free condition was maintained throughout the duration of the experiment by using rotary hand weeder, as well as manual weeding. For insect infestation, panyawan (Tinospora rumphii Boerl) + hot pepper + garlic + tobacco + soap extract was sprayed.

\section{Harvesting}

Harvesting was done when $85 \%$ of the grains in the panicle had ripened. The harvested grains were cleaned and dried to about $14 \%$ moisture content.

\section{Data Gathered}

\section{Morphological characteristics}

1. Phyllochron and leaf number - The phyllochron (day leaf ${ }^{-1}$ ) of each successive leaf on the main stem of each sample plants was determined for each measurement day, by dividing the time interval elapsed between the two consecutive Haun leaf number measurements (Wilhelm \& MacMaster 1995):

Phyllochron $=\frac{\text { interval between appearance of two consecutive leaves }(\text { day })}{\text { Haun stage difference between } 2 \text { dates of consecutive appearance }}$ 
The stage of development (Haun leaf number), the phyllochron of each leaf and total number of leaves on the main culm was measured every 5 days after planting (DAP) up to the complete exsertion of the flagleaf. For this purpose, five representative plants at the center rows of each plot were marked with bamboo sticks. The number of leaves of each marked seedlings was recorded during transplanting.

Haun leaf number was calculated according to the following formula (Haun 1973).

$$
\text { Haun leaf }=\left[L_{n} / L_{(n-1)}\right]+n-1
$$

where:

$$
\begin{aligned}
& L_{n}=\text { the length of the youngest leaf blade above the collar of subtending leaf } \\
& L_{(n-1)}=\text { the length of the blade of the penultimate (subtending) leaf } \\
& n=\text { the total number of leaves that are visible on the main culm }
\end{aligned}
$$

2. Aerenchyma cell formation - This was determined by measuring the size, number and total area of the aerenchyma cells per root cross section. Root samples were obtained by cutting a $10 \mathrm{~mm}$ section, at approximately $50 \mathrm{~mm}$ from the tip of the most prominent root. Fresh sectioning was done using a microtome. The cross root section was mounted in glass slide with Canada balsam. This was photographed using a digital camera.

Cell size was determined using a stage micrometer in a microscope. The total number of cells per root cross section was counted using the composite photos. The total area per root cross section was calculated by multiplying the mean size by the total aerenchyma cell.

3. Root pulling resistance (RPR) - This was measured using a $100 \mathrm{~kg}$ spring balance to estimate the root strength ( $0^{\prime}$ Toole \& Soemartono 1981). The plant was tied up with a small jute rope and pulled out with attached spring balance to obtain the RPR in $\mathrm{kg}$. The measurement was done at flowering.

4. Plant Height $(\mathrm{cm})$ was recorded from five randomly selected hills plot $^{-1}$. The measurement was done from the ground level to the tip of the panicle.

\section{Physiological Parameters}

1. Crop growth rate (CGR) - This is the rate of dry matter production per unit ground area per unit time. This was taken 3 weeks after transplanting until maturity, at two weeks interval. CGR was estimated using following formula:

$$
\operatorname{CGR}=\frac{W_{2}-W_{1}}{\left(T_{2}-T_{1}\right) L A}
$$

where:

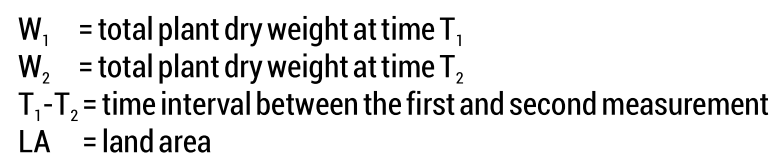


2. Net assimilation rate (NAR) - This is the rate of dry matter production per unit leaf area per unit time. It was calculated on the basis of dry matter and leaf area taken over the time. This was done biweekly, from vegetative to reproductive stage. Net assimilation rate was determined using the formula:

$$
\mathrm{NAR}=\frac{\left(\mathrm{W}_{2}-\mathrm{W}_{1}\right)\left(\ln L A_{2}-\operatorname{InLA} \mathrm{A}_{1}\right)}{\left(\mathrm{LA}_{2}-\mathrm{LA}_{1}\right)\left(\mathrm{T}_{2}-\mathrm{T}_{1}\right)}
$$

where:

$$
\begin{aligned}
& \text { In }=\text { natural logarithm } \\
& \mathrm{LA}_{1}=\text { leaf area at time } T_{1} \\
& \mathrm{LA}_{2}=\text { leaf area at time } \mathrm{T}_{2} \\
& \mathrm{~W}_{1}=\text { total plant dry weight at time } \mathrm{T}_{1} \\
& \mathrm{~W}_{2}=\text { total plant dry weight at time } \mathrm{T}_{2} \\
& \mathrm{~T}_{1}-\mathrm{T}_{2}=\text { time interval between the first and second measurement }
\end{aligned}
$$

3. Leaf Area Index (LAI) - This was measured using the procedure of Yoshida et al (1976) and Gomez (1972). This was determined from 6 sample hills plot ${ }^{-1}$ selected at random, at 45, 59, 73 and 86 days after transplant (DAT). From each selected hills, the number of tillers were counted. The length and the maximum width of each leaf in the middle tiller were measured. The middle tiller was the main tiller (during transplanting, a tag was placed at the leaf sheath). Leaf area and LAI was computed using the formula below:

$$
\begin{aligned}
& \text { Leaf area }=0.75 \times \mathrm{LxW} \\
& \text { Total leaf area/hill }=\text { total leaf area of middle tiller } x \text { total no. of tillers } \\
& \qquad \mathrm{LAI}=\frac{\text { sum of totalleaf area hill-1 } 1 \text { of six hills }\left(\mathrm{cm}^{2}\right)}{\text { area of land covered by six hills }\left(\mathrm{cm}^{2}\right)}
\end{aligned}
$$

4. Harvest Index $(\mathrm{HI})$ - This is the ratio of economic to biological yield. This was obtained by dividing the grain weight by total dry matter at harvest. Sample plants plot $^{-1}$ was oven dried at $80^{\circ} \mathrm{C}$ and weight was taken until constant dry weight was obtained.

This was computed using the following equation:

$$
\mathrm{HI}=\frac{\text { Economic yield (grain dry weight in } \mathrm{kg})}{\text { Biological yield (grain and straw dry weight in } \mathrm{kg})}
$$

\section{Yield and Yield Components}

1. Number of productive tiller $\mathrm{m}^{-2}$ was determined by counting all the tillers and the number of panicle-bearing tillers in one $(1) \mathrm{m}^{2}$. The number of tillers which bear no panicles or have less than five seeds per panicle was considered unproductive.

2. Number of filled spikelets panicle $e^{-1}$ was determined by manually counting all filled and unfilled spikelets of five (5) randomly selected panicles from each plot. 
3. Weight of 1,000 seeds $(\mathrm{g})$ was determined by weighing 1,000 seeds from each plot. Prior to measuring the weight, the moisture content was adjusted to $14 \%$.

4. Grain yield $\left(\mathrm{t} \mathrm{ha}^{-1}\right)$ was taken from the harvestable area plot ${ }^{-1}$ of $8.16 \mathrm{~m}^{2}$. Grain weight and moisture content were recorded. Yield was converted to $\mathrm{kg} \mathrm{ha}^{-1}$ and adjusted to $14 \% \mathrm{MC}$ and was then converted to tha ${ }^{-1}$.

\section{Statistical Analysis}

The data were analyzed using the Statistical Analysis System (SAS ver 6.12). Mean comparison was done using Honestly Significant Difference (HSD) or Tukey's test.

\section{RESULTS AND DISCUSSION}

\section{The Study Site}

The soil used in this experiment had favorable organic matter content at $3.12 \%$

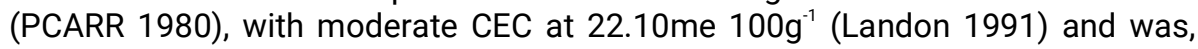
therefore, suitable for growth and development of the rice crop. Soil $\mathrm{pH}$ was medium acidic at 5.62 (PCARR 1980). Rice has been found to grow in a wide range of $\mathrm{pH}$, varying from $4-8$ (PCARRD 1986). Total $\mathrm{N}$ was low at $0.22 \%$, potassium was moderate at $181.26 \mathrm{mg} \mathrm{kg}^{-1}$ but phosphorous was deficient at $8.32 \mathrm{mg} \mathrm{kg}^{-1}$ (PCARR 1980).

Total monthly rainfall during the wet season was highest in February and lowest in December. In the dry season, total monthly rainfall was highest in June and lowest in May (Figure 1). The amount of rainfall under VSU condition is typically high, reaching an average of 2,809.6mm annual rainfall for the past 32 years (Escasinas \& Zamora 2011). This amount of rainfall is sufficient for rice production in the area. PCARRD (1986) reported that rice cultivation is limited to areas where annual rainfall exceeds $1000 \mathrm{~mm}$ and rice requires a rainfall of $1,240 \mathrm{~mm}$ per crop.

Higher solar radiation was recorded in the dry season. The range was from 11.3 $\mathrm{MJ} \mathrm{m}^{-2} \mathrm{~d}^{-1}$ to $12.3 \mathrm{MJ} \mathrm{m}^{-2} \mathrm{~d}^{-1}$ for the dry season and $9.5 \mathrm{MJ} \mathrm{m}^{-2} \mathrm{~d}^{-1}$ to $9.9 \mathrm{MJ} \mathrm{m}^{-2} \mathrm{~d}^{-1}$ for the wet season. A slight variation in temperature and wind speed was observed in both cropping seasons. The maximum and minimum temperatures ranged from 31.3 to $31.6^{\circ} \mathrm{C}$ and 23.9 to $23.9^{\circ} \mathrm{C}$, respectively, with a mean monthly temperature range of 27.6 to $27.8^{\circ} \mathrm{C}$ for the wet season. In the dry season, maximum and minimum temperatures range from $31.9^{\circ} \mathrm{C}$ to $32.2^{\circ} \mathrm{C}$ and $24.3^{\circ} \mathrm{C}$ to $24.7^{\circ} \mathrm{C}$ with a mean temperature ranging from $28.2^{\circ} \mathrm{C}$ to $28.5^{\circ} \mathrm{C}$.

In the wet season, highest wind speed was recorded in November at $1.26 \mathrm{~m} \mathrm{~s}^{-1}$ and lowest in December at $0.97 \mathrm{~m} \mathrm{~s}^{-1}$ when rice plants were at vegetative stage. In the dry season, highest wind speed was in April and June at $1.20 \mathrm{~m} \mathrm{~s}^{-1}$ and lowest in July at $0.90 \mathrm{~m} \mathrm{~s}^{-1}$ (Figure 1 ). 
Morphological and physiological performance of PSB Rc18 lowland rice

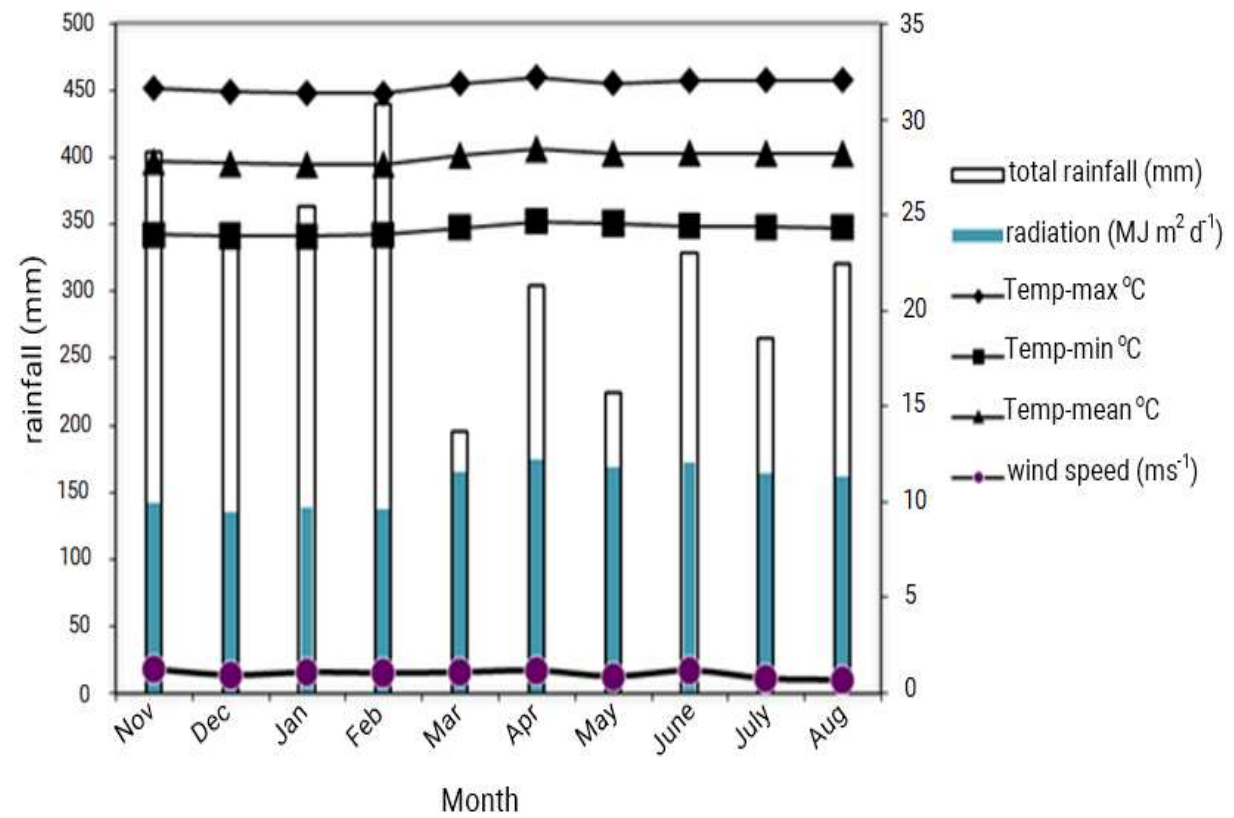

Figure 1. Total monthly rainfall, mean monthly solar radiation, maximum, minimum and mean temperature throughout the duration of the study

\section{Morphological Parameters}

\section{Phyllochron (day leaf ${ }^{\prime}$ ) and total number of leaves on the main culm}

Phyllochron is defined as the time interval between appearances of successive leaves on a culm (Wilhelm \& McMaster 1995) or the intervals of leaf emergence (Nemoto et al 1995). During the wet season, phyllochron at earlier stage of growth was longer $\left(\geq 7 \mathrm{dl}^{-1}\right)$ starting from the first leaf appearance until the emergence of leaf number 6 on the main culm (Table 1). Leaf number 8 had shorter phyllochron that ranged from 5-6day leaf ${ }^{-1}$, while later leaves had the shortest phyllochron of $\leq 4 \mathrm{~d} \mathrm{I}^{-1}$. During the dry season, longer phyllochron $\left(\geq 7 \mathrm{~d} \mathrm{I}^{-1}\right)$ was observed at leaf number 4 and 5 only (Table 2). Leaf number 6 , until the emergence of leaf number 11 , had phyllochron that ranged from $5-6 \mathrm{~d} \mathrm{l}^{-1}$. Later leaves had shorter phyllochron of $\geq 3 \mathrm{~d} l^{-1}$. Generally, early growth stages tended to have longer phyllochron in both cropping seasons because of transplanting shock, hence longer time and more energy were needed for leaf formation (Tables 1 \& 2).

The duration of phyllochron in rice can be short or long, depending on the agronomic management practices, genotype and environmental conditions. When rice plants are grown under appropriate spacing and planting density, soil nutrient, water management and other suitable requisites, phyllochron can be completed within 5 to 7 days. With this growth rate, a dozen of phyllochron could be observed before panicle initiation begins, with a possible summation of 84 tillers per plant (ATS \& de Laulanie 1993). When the rate of biological growth is speeded up, many growth parameters such as leaves, tillers and roots can be produced before panicle initiation begins, resulting in higher yield. 
Phyllochron was not affected by spacing in this study, implying that the spacings used were appropriate for better light interception and distribution. This finding contradicted the finding of Enquayehush (2004), who found that phyllochron in rice was significantly affected by spacing in both dry and wet seasons. The total number of leaves on the main culm was 14 during the wet and 15 in dry season. This parameter was not affected either by fertilizer and spacing in both cropping seasons (Tables $1 \& 2$ ).

Table 1. Phyllochron (day leaf ${ }^{-1}$ ) of each leaf (after transplanting) and total leaf number of PSB Rc18 as affected by fertilizer and spacing during wet season (07-08)

\begin{tabular}{|c|c|c|c|c|c|c|c|c|c|c|c|c|c|}
\hline \multirow{2}{*}{$\begin{array}{c}\text { Spacing } \\
(\mathrm{cm})\end{array}$} & \multicolumn{12}{|c|}{ Leaf Number } & \multirow{2}{*}{$\begin{array}{l}\text { Total } \\
\text { Leaf }\end{array}$} \\
\hline & 1 & 2 & 3 & 4 & 5 & 6 & 8 & 9 & 11 & 13 & 15 & 17 & \\
\hline \multicolumn{14}{|c|}{ Goat Manure } \\
\hline $20 \times 20$ & & & & 7 & 11 & 7 & 5 & 4 & 4 & 4 & 4 & 3 & 14 \\
\hline $40 \times 10$ & & & & 7 & 9 & 8 & 5 & 4 & 4 & 4 & 4 & 3 & 14 \\
\hline $40 \times 40$ & & & & 7 & 9 & 8 & 6 & 4 & 3 & 3 & 4 & 4 & 14 \\
\hline \multicolumn{14}{|c|}{ Compost Mixture } \\
\hline $20 \times 20$ & & & & 7 & 12 & 7 & 6 & 3 & 4 & 3 & 4 & 3 & 14 \\
\hline $40 \times 10$ & & & & 7 & 8 & 9 & 5 & 3 & 3 & 4 & 4 & 3 & 14 \\
\hline $40 \times 40$ & & & & 7 & 10 & 7 & 6 & 4 & 3 & 4 & 4 & 3 & 14 \\
\hline \multicolumn{14}{|c|}{ Inorganic Fertilizer } \\
\hline $20 \times 20$ & & & & 7 & 9 & 8 & 5 & 4 & 4 & 3 & 4 & 3 & 14 \\
\hline $40 \times 10$ & & & & 7 & 9 & 8 & 6 & 4 & 3 & 4 & 4 & 3 & 14 \\
\hline $40 \times 40$ & & & & 7 & 8 & 8 & 6 & 4 & 4 & 3 & 4 & 3 & 14 \\
\hline \multicolumn{14}{|c|}{ Control } \\
\hline $20 \times 20$ & & & & 7 & 12 & 8 & 5 & 4 & 3 & 4 & 4 & 3 & 14 \\
\hline $40 \times 10$ & & & & 7 & 10 & 8 & 5 & 4 & 4 & 3 & 4 & 4 & 14 \\
\hline $40 \times 40$ & & & & 7 & 10 & 7 & 6 & 4 & 3 & 4 & 4 & 3 & 14 \\
\hline
\end{tabular}

Table 2. Phyllochron (day leaf ${ }^{-1}$ ) of each leaf (after transplanting) and total leaf number of PSB Rc18 as affected by fertilizer and spacing during dry season (2008)

\begin{tabular}{|c|c|c|c|c|c|c|c|c|c|c|c|c|c|c|}
\hline \multirow{2}{*}{$\begin{array}{l}\text { Spacing } \\
(\mathrm{cm})\end{array}$} & \multicolumn{13}{|c|}{ Leaf Number } & \multirow{2}{*}{$\begin{array}{l}\text { Total } \\
\text { Leaf }\end{array}$} \\
\hline & 1 & 2 & 3 & 4 & 5 & 6 & 8 & 9 & 11 & 13 & 15 & 17 & 18 & \\
\hline \multicolumn{15}{|c|}{ Goat Manure } \\
\hline $20 \times 20$ & & & & 7 & 8 & 5 & 6 & 6 & 6 & 5 & 4 & 4 & 3 & 15 \\
\hline $40 \times 10$ & & & & 7 & 7 & 6 & 6 & 5 & 5 & 4 & 5 & 5 & 3 & 15 \\
\hline $40 \times 40$ & & & & 8 & 8 & 5 & 6 & 6 & 6 & 6 & 4 & 5 & 4 & 15 \\
\hline \multicolumn{15}{|c|}{ Compost Mixture } \\
\hline $20 \times 20$ & & & & 7 & 7 & 6 & 5 & 6 & 6 & 4 & 4 & 5 & 4 & 15 \\
\hline $40 \times 10$ & & & & 8 & 7 & 6 & 5 & 5 & 6 & 6 & 6 & 5 & 4 & 15 \\
\hline $40 \times 40$ & & & & 7 & 8 & 6 & 5 & 5 & 6 & 5 & 4 & 5 & 4 & 15 \\
\hline \multicolumn{15}{|c|}{ Inorganic Fertilizer } \\
\hline $20 \times 20$ & & & & 8 & 8 & 6 & 6 & 6 & 5 & 5 & 4 & 4 & 3 & 15 \\
\hline $40 \times 10$ & & & & 7 & 8 & 6 & 6 & 5 & 5 & 6 & 5 & 4 & 3 & 15 \\
\hline $40 \times 40$ & & & & 7 & 8 & 6 & 5 & 6 & 5 & 4 & 4 & 5 & 4 & 15 \\
\hline
\end{tabular}


Morphological and physiological performance of PSB Rc18 lowland rice

\begin{tabular}{|c|c|c|c|c|c|c|c|c|c|c|c|c|c|c|}
\hline \multirow{2}{*}{$\begin{array}{l}\text { Spacing } \\
(\mathrm{cm})\end{array}$} & \multicolumn{13}{|c|}{ Leaf Number } & \multirow{2}{*}{$\begin{array}{l}\text { Total } \\
\text { Leaf }\end{array}$} \\
\hline & 1 & 2 & 3 & 4 & 5 & 6 & 8 & 9 & 11 & 13 & 15 & 17 & 18 & \\
\hline \multicolumn{15}{|c|}{ Control } \\
\hline $20 \times 20$ & & & & 8 & 8 & 5 & 5 & 5 & 6 & 5 & 5 & 5 & 3 & 15 \\
\hline $40 \times 10$ & & & & 7 & 8 & 6 & 5 & 5 & 6 & 4 & 4 & 4 & 3 & 15 \\
\hline $40 \times 40$ & & & & 7 & 8 & 6 & 6 & 6 & 6 & 5 & 4 & 5 & 4 & 15 \\
\hline
\end{tabular}

\section{Root aerenchyma, cell number and measurement}

Rice plants grown under continuous flooding and no flooding treatment both formed aerenchyma cells in their roots (Figures $2 \& 3$ ). The number and cell size were statistically similar as well (Table 3 ).

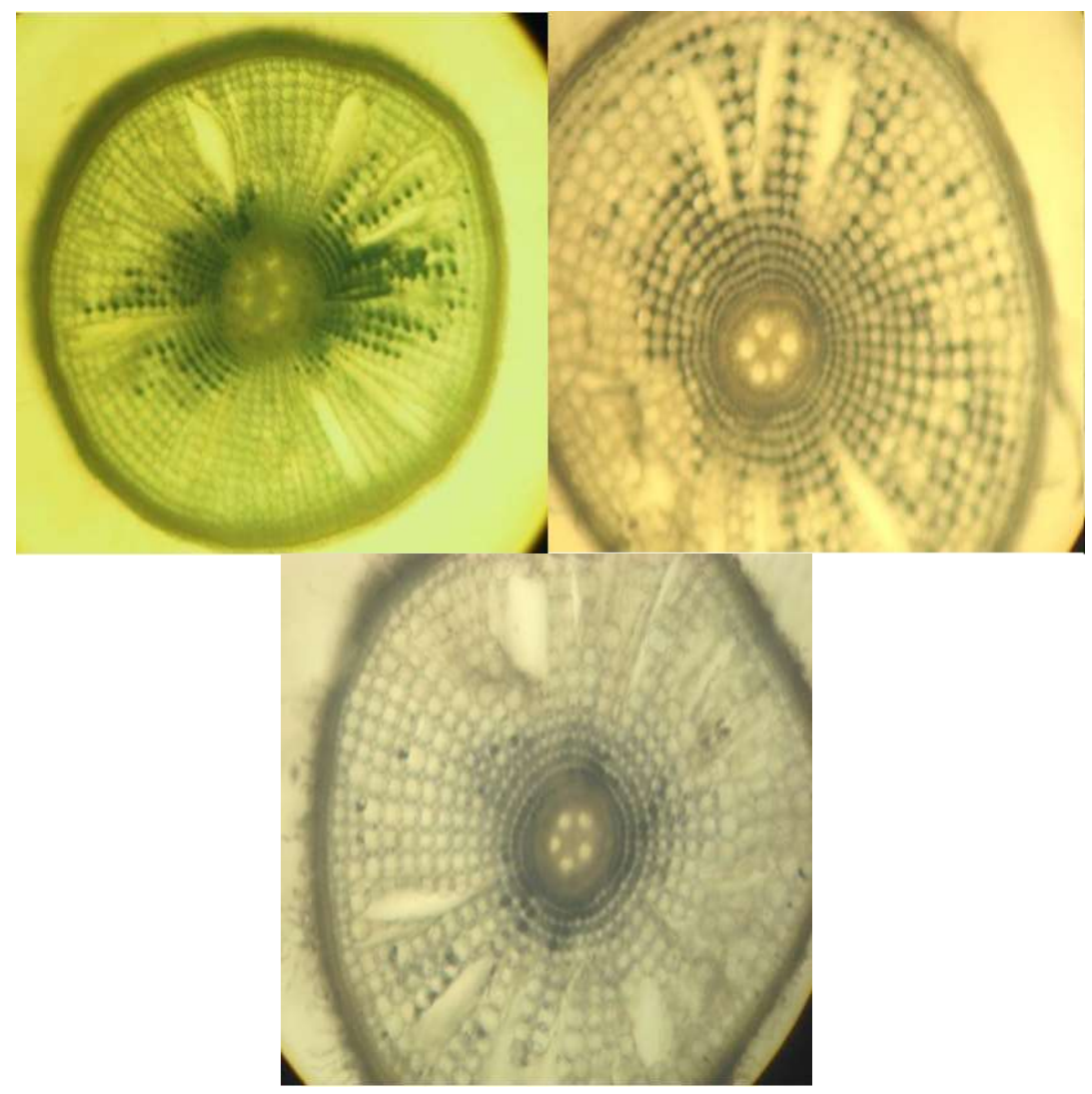

Figure 2. Aerenchyma root cells of PSB Rc18 at panicle initiation under no flooding conditions

Jackson et al (1985) found that in rice, aerenchyma forms speedily even in wellaerated, flooded and drained treatments. Aerenchyma is formed either as part of normal development or in response to stress, eg hypoxia (Evans 2003). Aerenchyma is always present in the roots of several genotypes, independent of 
environmental factors. However the volume of aerenchyma varies with genotype (Barber et al 1962, Justin \& Armstrong 1991). In contrast, roots of other cereals only develop aerenchyma under waterlogging, eg, in maize and wheat, aerenchyma forms only in roots in stagnant solutions or at low $\mathrm{O}_{2}$ concentrations (IRRI 1995).

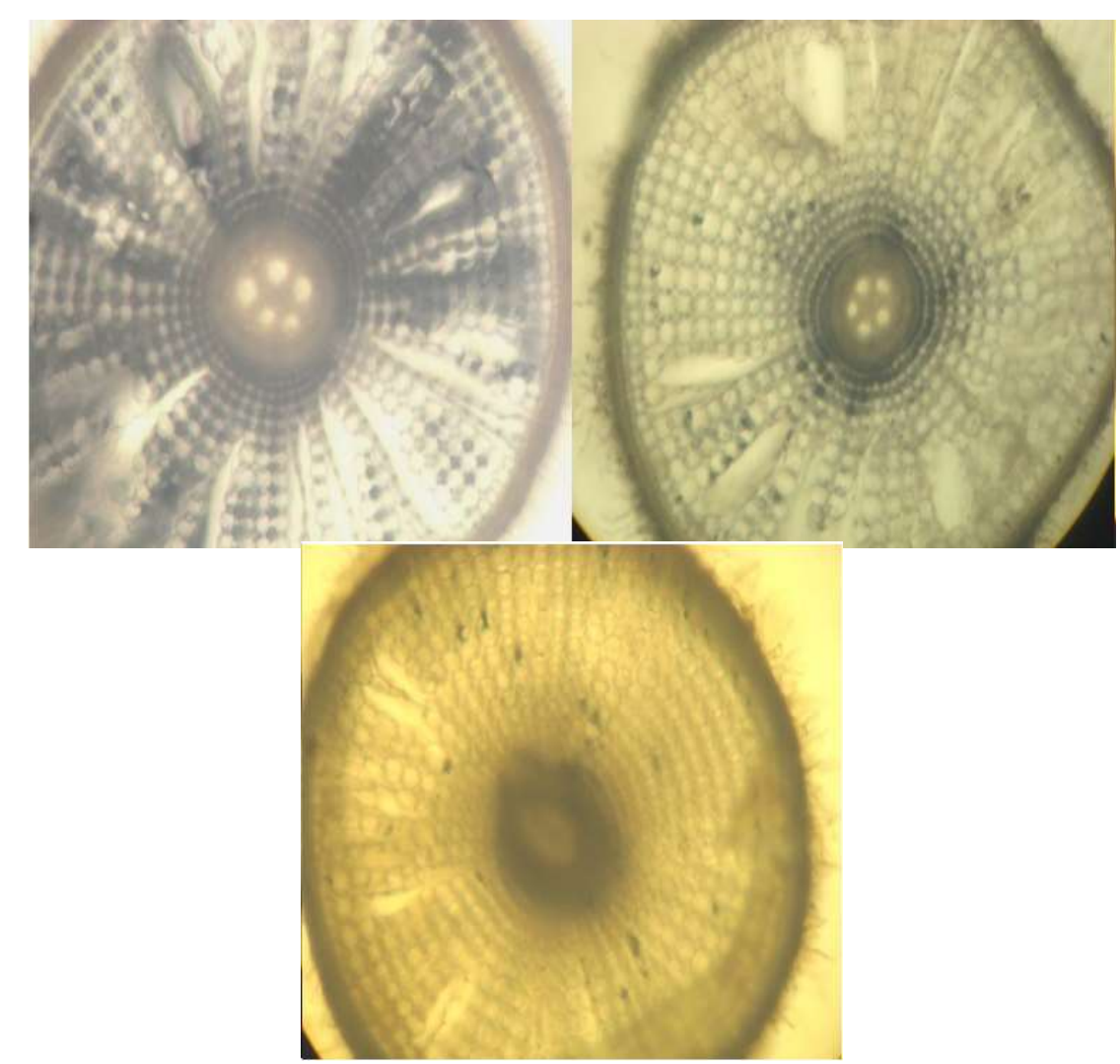

Figure 3. Aerenchyma root cells of PSB Rc18 at panicle initiation under continuous flooding conditions

Table 3. Aerenchyma cell number and total area $\left(\mathrm{mm}^{2}\right)$ of lowland rice at panicle initiation as affected by water management, fertilizer and plant spacing during dry seasons (2008)

\begin{tabular}{llc}
\hline \multicolumn{1}{c}{ Treatments } & Cell Number & Total Area $\left(\mathrm{mm}^{2}\right)$ \\
\hline Water Management & & \\
$\quad$ Continuous Flooding (WM1) & $8.03 \mathrm{a}$ & $0.125 \mathrm{a}$ \\
$\quad$ No Flooding (WM2) & $8.22 \mathrm{a}$ & $0.125 \mathrm{a}$ \\
HSD 0.05 & 0.69 & 0.122 \\
Fertilizer & & \\
Goat Manure (F1) & $8.11 \mathrm{a}$ & $0.128 \mathrm{a}$ \\
Compost mixture (F2) & $8.33 \mathrm{a}$ & $0.127 \mathrm{a}$ \\
Inorganic fertilizer (F3) & $7.89 \mathrm{a}$ & $0.118 \mathrm{a}$ \\
Control (F4) & $8.17 \mathrm{a}$ & $0.125 \mathrm{a}$ \\
HSD 0.05 & 1.31 & 0.023 \\
\hline
\end{tabular}


Morphological and physiological performance of PSB Rc18 lowland rice

Table 3 continued

\begin{tabular}{ccc} 
Treatments & Cell Number & Total Area $\left(\mathrm{mm}^{2}\right)$ \\
\hline Spacing & & \\
$20 \times 20 \mathrm{~cm}(\mathrm{~S} 1)$ & $8.00 \mathrm{a}$ & $0.125 \mathrm{a}$ \\
$40 \times 10 \mathrm{~cm}(\mathrm{~S} 2)$ & $7.88 \mathrm{a}$ & $0.122 \mathrm{a}$ \\
$40 \times 40 \mathrm{~cm}(\mathrm{~S} 3)$ & $8.50 \mathrm{a}$ & $0.127 \mathrm{a}$ \\
HSD 0.05 & 1.03 & 0.018 \\
\hline
\end{tabular}

Means within a column followed by the same letter are not significantly different at $5 \%$, HSD

Puard et al (1986) stated that aerenchyma cells are adaptations that enable the roots to survive under anaerobic (hypoxic) conditions but with some cost to the plants. While aerenchyma facilitates oxygen transport to the root tip and to the rhizosphere and remove gases ( $\mathrm{CO} 2$, ethylene \& methane) from root and soil (Shannon et al 1986, Colmer 2003), loss of cortex tissue can impede root functions such as water and mineral uptake and transport. Aerenchyma provides a low resistance pathway for venting of methane from rhizosphere to the atmosphere (Evans 2003).

\section{Root pulling resistance $(\mathrm{kg})$}

No flooding treatment had the highest root pulling resistance in both cropping seasons. Similarly, wider spacing resulted in higher root pulling resistance compared to closer spacing. Interaction between water management and spacing on root pulling resistance was recorded in both cropping seasons (Tables $4 \& 5$ ).

Table 4. Water management $x$ spacing interaction of root pulling resistance $(\mathrm{kg})$ at flowering during the wet season (07-08)

\begin{tabular}{ccc}
\hline & Root Pulling Resistance $(\mathrm{kg})$ \\
\hline Spacing & Continuous flooding & No flooding \\
\hline $20 \times 20 \mathrm{~cm}$ & $10.42 \mathrm{c}$ & $22.38 \mathrm{~b}$ \\
$40 \times 10 \mathrm{~cm}$ & $12.04 \mathrm{c}$ & $24.21 \mathrm{~b}$ \\
$40 \times 40 \mathrm{~cm}$ & $20.96 \mathrm{~b}$ & $42.58 \mathrm{a}$ \\
\hline
\end{tabular}

Means followed by a common letter across water management and spacing are not significantly different at $5 \%$ level, HSD

Table 5. Water management $x$ spacing interaction of root pulling resistance $(\mathrm{kg})$ at flowering during the dry season (2008)

\begin{tabular}{ccc}
\hline & Root Pulling Resistance $(\mathrm{kg})$ & \\
\hline Spacing & Continuous flooding & No flooding \\
\hline $20 \times 20 \mathrm{~cm}$ & $18.62 \mathrm{~d}$ & $35.92 \mathrm{c}$ \\
$40 \times 10 \mathrm{~cm}$ & $21.50 \mathrm{~d}$ & $36.88 \mathrm{c}$ \\
$40 \times 40 \mathrm{~cm}$ & $42.33 \mathrm{~b}$ & $53.08 \mathrm{a}$ \\
\hline
\end{tabular}

Means followed by a common letter across water management and spacing are not significantly different at $5 \%$ level, HSD 
Highest root pulling resistance was observed in the treatment combination of no flooding and wider spacing $(40 \mathrm{~cm} \times 40 \mathrm{~cm})$. This was followed by no flooding and closer spacing $(40 \mathrm{~cm} \times 10 \mathrm{~cm} \& 20 \mathrm{~cm} \times 20 \mathrm{~cm}$, respectively) which was statistically similar with treatment combination of continuous flooding and wider spacing. The lowest was observed at treatment combination of continuous flooding and closer spacing.

The higher root pulling resistance at wider spacing was due to more tillers hill' ${ }^{-1}$, resulting to more roots anchoring the soil. More tillers means greater number and density of roots. Hence, it is expected that plants at wider spacing are sturdier than those at closer spacing which experience more intense competition, especially for solar radiation (both quality \& quantity) that affects tiller production (Escasinas \& Zamora 2011).

\section{Plant height (cm)}

Reduced plant height was recorded under no flooding condition. George et al (2001) stated that Magat rice had reduced plant height in aerobic soil; its height was substantially lower than its usual height of $1 \mathrm{~m}$ in flooded soil. This characteristic will likely account to lodging resistance even at high grain yield.

Plants in the wet season applied with inorganic fertilizer were significantly taller compared to the other treatments. This could be due to the immediate release of nutrients by inorganic fertilizer which were made available for plant use at earlier period. In the dry season, the same treatment produced taller plants. However, this was statistically at par with those applied with goat manure. Organic fertilizer released nutrients slowly hence its effect was observed in the dry season $\left(2^{\text {nd }}\right.$ cropping) only. Unfertilized plants were the shortest.

Plants at wider spacing $(40 \mathrm{~cm} \times 40 \mathrm{~cm})$ were significantly taller compared to those plants at closer spacing during dry season (Table 6 ). This could be explained by better access to nutrients, water and solar radiation that enhanced growth and development under this condition. This agrees with the findings of Vijayakumar et al (2006) who reported that plants at wider spacing grew taller because of increased shoot : root ratio. Ultimately, the plants were able to get sufficient space to grow and the increased light transmission in the canopy led to increased plant height.

Table 6. Plant height $(\mathrm{cm})$ of lowland rice at maturity as affected by water management, fertilizer and plant spacing during wet (07-08) and dry (2008) seasons

\begin{tabular}{lcc}
\hline \multicolumn{1}{c}{ Treatments } & Wet Season & Dry Season \\
\hline Water Management & $99.97 \mathrm{a}$ & $124.50 \mathrm{a}$ \\
Continuous Flooding (WM1) & $97.96 \mathrm{~b}$ & $118.69 \mathrm{~b}$ \\
$\quad$ No Flooding (WM2) & 1.70 & 3.21 \\
HSD 0.05 & & \\
Fertilizer & $96.63 \mathrm{~b}$ & $123.27 \mathrm{ab}$ \\
Goat Manure (F1) & $97.21 \mathrm{~b}$ & $122.24 \mathrm{~b}$ \\
Compost mixture (F2) & $103.83 \mathrm{a}$ & $128.55 \mathrm{a}$ \\
Inorganic fertilizer (F3) & $97.57 \mathrm{~b}$ & $112.34 \mathrm{c}$ \\
Control (F4) & 3.20 & 6.05 \\
HSD 0.05 & & \\
\hline
\end{tabular}


Morphological and physiological performance of PSB Rc18 lowland rice

\begin{tabular}{lcc} 
Table 6 continued & & \\
\hline Treatments & Wet Season & Dry Season \\
\hline Spacing & 98.15 & $118.75 \mathrm{~b}$ \\
$20 \times 20 \mathrm{~cm}(\mathrm{~S} 1)$ & 99.41 & $119.89 \mathrm{~b}$ \\
$40 \times 10 \mathrm{~cm}(\mathrm{~S} 2)$ & 98.88 & $126.16 \mathrm{a}$ \\
$40 \times 40 \mathrm{~cm}(\mathrm{~S} 3)$ & NS & 4.75 \\
HSD 0.05 & &
\end{tabular}

Means within a column followed by the same letter are not significantly different at $5 \%, \mathrm{HSD}$

\section{Physiological Parameters}

\section{Crop growth rate $\left(\mathrm{g} \mathrm{m}^{-2} \mathrm{~d}^{-1}\right)$}

During the wet season, there was a highly significant interaction in crop growth rate (CGR) among water management $x$ fertilizer $x$ plant spacing at 73-86 days after transplanting but not at 59-73 DAT (Table 7). Moreover, fertilizer and spacing highly influenced the CGR at all sampling periods while water management significantly affected CGR at only 45-59 DAT. Higher CGR value of $33.77 \mathrm{~g} \mathrm{~m}^{-2} \mathrm{~d}^{-1}$ was recorded in plants fertilized with inorganic fertilizer planted at closer spacing $(20 \times 20 \mathrm{~cm})$ under no flooding. This treatment was comparable to plants at $40 \mathrm{~cm} \times 10 \mathrm{~cm}$, fertilized with inorganic fertilizer. Lower CGR occurred at wider spacing $(40 \mathrm{~cm} \times 40 \mathrm{~cm})$ applied with either organic or inorganic fertilizers and subjected to either continuous flooding or no flooding.

Table 7 . Crop growth rate as affected by water management $x$ fertilizer $x$ spacing interaction at 73 86 days after transplanting during the wet season (07-08)

\begin{tabular}{ccccc}
\hline \multicolumn{5}{c}{ Crop Growth Rate $\left(\mathrm{g} \mathrm{m}^{-2} \mathrm{~d}^{-1}\right)$} \\
\hline & Goat manure & Compost mixture & Inorganic & Control \\
\hline Continuous flooding & & & & \\
$20 \times 20 \mathrm{~cm}$ & $19.36 \mathrm{abcd}$ & $24.75 \mathrm{abc}$ & $15.97 \mathrm{bcd}$ & $16.66 \mathrm{bcd}$ \\
$40 \times 10 \mathrm{~cm}$ & $12.45 \mathrm{~cd}$ & $19.41 \mathrm{abcd}$ & $22.79 \mathrm{abc}$ & $19.30 \mathrm{abcd}$ \\
$40 \times 40 \mathrm{~cm}$ & $9.07 \mathrm{~cd}$ & $9.56 \mathrm{~cd}$ & $13.66 \mathrm{bcd}$ & $10.42 \mathrm{~cd}$ \\
No Flooding & & & & \\
$20 \times 20 \mathrm{~cm}$ & $21.25 \mathrm{abcd}$ & $18.10 \mathrm{abcd}$ & $33.77 \mathrm{a}$ & $15.37 \mathrm{bcd}$ \\
$40 \times 10 \mathrm{~cm}$ & $17.74 \mathrm{abcd}$ & $15.14 \mathrm{bcd}$ & $29.63 \mathrm{ab}$ & $14.46 \mathrm{bcd}$ \\
$40 \times 40 \mathrm{~cm}$ & $7.68 \mathrm{~d}$ & $10.89 \mathrm{~cd}$ & $15.44 \mathrm{bcd}$ & $9.54 \mathrm{~cd}$ \\
\hline
\end{tabular}

Means followed by common letter(s) across water management, fertilizer and spacing are not significantly different using HSD $5 \%$

There was significant interaction between water management $x$ fertilizer $x$ spacing at 73-86 DAT, respectively, during the dry season (Table 8). The trend was similar during the wet season, where higher CGR value was recorded at closer spacing with plants applied with inorganic fertilizer under no flooding condition. Lower CGR on the other hand, was observed at wider spacing with plants applied with either organic or inorganic fertilizer, either in continuous flooding or no flooding condition. 
Table 8. Crop growth rate as affected by water management $x$ fertilizer $x$ spacing interaction at 73 86 days after transplanting during the dry season (2008)

\begin{tabular}{cclll}
\hline \multicolumn{5}{c}{ Crop Growth Rate $\left(\mathrm{g} \mathrm{m}^{-2} \mathrm{~d}^{-1}\right)$} \\
\hline Spacing & Goat manure & Compost mixture & Inorganic & Control \\
\hline Continuous flooding $(\mathrm{cm})$ & & & & \\
$20 \times 20$ & $21.24 \mathrm{abcd}$ & $22.63 \mathrm{abc}$ & $24.04 \mathrm{ab}$ & $16.24 \mathrm{abcd}$ \\
$40 \times 10$ & $26.56 \mathrm{abcd}$ & $12.90 \mathrm{abcd}$ & $21.18 \mathrm{abcd}$ & $16.89 \mathrm{abcd}$ \\
$40 \times 40$ & $9.79 \mathrm{abcd}$ & $9.12 \mathrm{abcd}$ & $5.18 \mathrm{~cd}$ & $5.70 \mathrm{~cd}$ \\
No Flooding & & & & \\
$20 \times 20$ & $14.22 \mathrm{abcd}$ & $16.08 \mathrm{abcd}$ & $16.08 \mathrm{abcd}$ & $16.74 \mathrm{abcd}$ \\
$40 \times 10$ & $13.86 \mathrm{abcd}$ & $19.80 \mathrm{abcd}$ & $26.62 \mathrm{a}$ & $18.46 \mathrm{abcd}$ \\
$40 \times 40$ & $4.66 \mathrm{~cd}$ & $6.41 \mathrm{bcd}$ & $7.88 \mathrm{bcd}$ & $6.69 \mathrm{bcd}$ \\
\hline
\end{tabular}

Means followed by a common letter across water management, fertilizer and spacing are not significantly different at $5 \%$ HSD

Consistently low CGR values were recorded at wider spacing $(40 \mathrm{~cm} \times 40 \mathrm{~cm})$ at 73-86 DAT (Tables $7 \&$ 8) because in this period, the plants were already at the flowering to milking stage, hence growth was very slow. Moreover, at wider spacing, it is expected to have lower CGR values because of the bigger area. This result contradicts the findings of Vijayakamur et al (2006) who observed higher CGR at wider spacing due to lesser competition among plants that will boost more $\mathrm{CHO}$ assimilation, leading to more total dry matter production (TDMP). However, the author further stated that at initial growth stages, closer spacing recorded higher CGR values due to more number of tillers and leaves per unit area. CGR at closer spacing was consistently higher than those at wider spacing.

\section{Net assimilation rate $\left(\mathrm{g} \mathrm{m}^{-2} \mathrm{~d}^{-1}\right)$}

There were significant interactions between fertilizer $x$ spacing and water management $x$ fertilizer at 73-86 DAT during wet season. Higher NAR was recorded at wider spacing with plants applied with goat manure. This treatment was not significantly different from those treated with inorganic fertilizer. Lowest NAR was observed in the control plants under closer spacing (Table 9). There was significant interaction between water management and fertilizer; ie, higher net assimilation rate occurred in plants applied with goat manure under continuous flooding but statistically at par with those plants applied with inorganic fertilizer at $90-30-30 \mathrm{~kg} \mathrm{~N}$, $\mathrm{P}_{2} \mathrm{O}_{5}, \mathrm{~K}_{2} \mathrm{O} \mathrm{ha}^{-1}$, both in continuous flooding and no flooding (Table 10).

Table 9. Interaction between fertilizer and spacing on net assimilation rate at 73-86 days after transplanting during the wet season (07-08)

\begin{tabular}{ccccc}
\hline \multicolumn{5}{c}{ Net Assimilation Rate $\left(\mathrm{g} \mathrm{m}^{-2} \mathrm{~d}^{-1}\right)$} \\
\hline Spacing & Goat Manure & Compost Mixture & Inorganic & Control \\
\hline $20 \times 20 \mathrm{~cm}$ & $6.80 \mathrm{abc}$ & $9.80 \mathrm{ab}$ & $8.72 \mathrm{abc}$ & $3.93 \mathrm{c}$ \\
$40 \times 10 \mathrm{~cm}$ & $4.61 \mathrm{bc}$ & $6.08 \mathrm{abc}$ & $7.75 \mathrm{abc}$ & $4.18 \mathrm{c}$ \\
$40 \times 40 \mathrm{~cm}$ & $10.19 \mathrm{a}$ & $8.48 \mathrm{abc}$ & $10.15 \mathrm{a}$ & $6.87 \mathrm{abc}$ \\
\hline
\end{tabular}

Means followed by a common letter across fertilizer and spacing are not significantly different at $5 \%$ HSD 
Morphological and physiological performance of PSB Rc18 lowland rice

Table 10. Net assimilation rate as affected by water management $x$ fertilizer interaction at $45-59$ days after transplanting during the wet season (07-08)

\begin{tabular}{|c|c|c|}
\hline \multicolumn{3}{|c|}{ Net Assimilation Rate $\left(\mathrm{g} \mathrm{m}^{-2} \mathrm{~d}^{-1}\right)$} \\
\hline & Continuous flooding & No flooding \\
\hline Goat manure & $25.21 a$ & $12.63 b$ \\
\hline Compost mixture & $14.92 b$ & $14.75 b$ \\
\hline Inorganic & $18.68 a b$ & $20.33 a b$ \\
\hline Control & $12.70 \mathrm{~b}$ & $14.02 \mathrm{~b}$ \\
\hline
\end{tabular}

During dry season, the interaction between water management $x$ spacing affected NAR but was significant only at 73-86 DAT. Highest NAR was recorded at $40 \mathrm{~cm} \times 40 \mathrm{~cm}$ under no flooding $(\mathrm{Wm} 2)$. This was statistically similar with values at $40 \times 10 \mathrm{~cm}$ under continuous flooding (Table 11). Significant water management $x$ fertilizer interaction was likewise observed at 73-86 DAT. Plants applied with organic fertilizer had NAR comparable to inorganic fertilizer under continuous flooding. Goat manure application had higher NAR comparable to inorganic fertilizer application under no flooding condition (Table 12).

Table 11. Water management $x$ spacing interaction on net assimilation rate at 73-86 days after transplanting during the dry season (2008)

\begin{tabular}{lcc}
\hline & Net Assimilation Rate $\left(\mathrm{g} \mathrm{m}^{-2} \mathrm{~d}^{-1}\right)$ & \\
\hline $20 \times 20 \mathrm{~cm}$ & Continuous flooding & No flooding \\
$40 \times 10 \mathrm{~cm}$ & $4.09 \mathrm{~b}$ & $3.76 \mathrm{~b}$ \\
$40 \times 40 \mathrm{~cm}$ & $5.51 \mathrm{ab}$ & $4.29 \mathrm{~b}$ \\
\hline Means followed by a common letter across water management and spacing are not significantly different at $5 \% \mathrm{HSD}$
\end{tabular}

Table 12. Net assimilation rate as affected by water management $x$ fertilizer interaction at 73-86 days after transplanting during the dry season (2008)

\begin{tabular}{lcc}
\hline \multicolumn{3}{c}{ Net Assimilation Rate $\left(\mathrm{g} \mathrm{m}^{-2} \mathrm{~d}^{-1}\right)$} \\
\hline Goat manure & Continuous flooding & No Flooding \\
Compost mixture & $9.98 \mathrm{ab}$ & $14.76 \mathrm{ab}$ \\
Inorganic & $16.13 \mathrm{a}$ & $9.85 \mathrm{~b}$ \\
Control & $14.58 \mathrm{ab}$ & $10.36 \mathrm{ab}$ \\
Means followed by a common letter across water management and fertilizer are not significantly different at 5\% HSD
\end{tabular}

\section{Leaf area index}

The interaction between water management $x$ fertilizer $x$ spacing on LAI was observed at 59 DAT during the wet season (Table 13). Highest LAI (6.61) was recorded in plants applied with inorganic fertilizer at closer spacing $(40 \times 10 \mathrm{~cm})$ under no flooding, while the lowest (1.19) was obtained in unfertilized plants at wider spacing under the same water management. 
Table 13. Leaf area index of lowland rice affected by water management $x$ fertilizer $x$ spacing interaction at 59 days after transplanting during wet season (07-08)

\begin{tabular}{cllll}
\hline \multicolumn{5}{c}{ Leaf Area Index } \\
\cline { 1 - 3 } Continuous flooding & Goat manure & Compost mixture & Inorganic & \multicolumn{1}{c}{ Control } \\
$20 \times 20 \mathrm{~cm}$ & $4.04 \mathrm{abcde}$ & $4.34 \mathrm{abcd}$ & $5.90 \mathrm{ab}$ & $3.97 \mathrm{abcde}$ \\
$40 \times 10 \mathrm{~cm}$ & $3.81 \mathrm{abcde}$ & $3.61 \mathrm{abcde}$ & $5.77 \mathrm{ab}$ & $3.70 \mathrm{abcde}$ \\
$40 \times 40 \mathrm{~cm}$ & $1.83 \mathrm{cde}$ & $1.38 \mathrm{de}$ & $1.41 \mathrm{de}$ & $1.69 \mathrm{de}$ \\
No Flooding & & & & \\
$20 \times 20 \mathrm{~cm}$ & $5.10 \mathrm{ab}$ & $3.68 \mathrm{abcde}$ & $5.08 \mathrm{ab}$ & $3.93 \mathrm{abcde}$ \\
$40 \times 10 \mathrm{~cm}$ & $4.43 \mathrm{abcd}$ & $4.92 \mathrm{abc}$ & $6.61 \mathrm{a}$ & $4.37 \mathrm{abcd}$ \\
$40 \times 40 \mathrm{~cm}$ & $1.30 \mathrm{e}$ & $1.62 \mathrm{de}$ & $2.90 \mathrm{bcde}$ & $1.19 \mathrm{de}$ \\
\hline
\end{tabular}

Means followed by a common letter across water management, fertilizer and spacing are not significantly different at $5 \% \mathrm{HSD}$

During the dry season, there was interaction between water management $x$ fertilizer $x$ spacing at 45 DAT on LAI (Table 14). Like in the wet season, highest LAI was recorded in plants applied with inorganic fertilizer planted at closer spacing $(40 \mathrm{~cm} \times 10 \mathrm{~cm})$ but under continuous flooding. The lowest was in unfertilized plants at wider spacing under continuous flooding but statistically at par with no flooding.

Table 14. Leaf area index of lowland rice affected by water management $x$ fertilizer $x$ spacing interaction at 45 days after transplanting during the dry season (2008)

\begin{tabular}{cllll}
\hline & & Leaf Area Index & \\
\hline & Goat manure & Compost mixture & Inorganic & control \\
\hline Continuous flooding & & & & \\
$20 \times 20 \mathrm{~cm}$ & $4.67 \mathrm{abc}$ & $3.29 \mathrm{cdef}$ & $5.86 \mathrm{ab}$ & $3.87 \mathrm{abcde}$ \\
$40 \times 10 \mathrm{~cm}$ & $4.16 \mathrm{abcd}$ & $3.71 \mathrm{bcde}$ & $6.20 \mathrm{a}$ & $3.74 \mathrm{abcde}$ \\
$40 \times 40 \mathrm{~cm}$ & $1.51 \mathrm{ef}$ & $1.47 \mathrm{ef}$ & $2.49 \mathrm{cdef}$ & $0.89 \mathrm{f}$ \\
No Flooding & & & & \\
$20 \times 20 \mathrm{~cm}$ & $3.15 \mathrm{cdef}$ & $3.21 \mathrm{cdef}$ & $5.98 \mathrm{ab}$ & $2.22 \mathrm{cdef}$ \\
$40 \times 10 \mathrm{~cm}$ & $2.92 \mathrm{cdef}$ & $2.67 \mathrm{cdef}$ & $5.90 \mathrm{ab}$ & $2.08 \mathrm{def}$ \\
$40 \times 40 \mathrm{~cm}$ & $1.22 \mathrm{f}$ & $1.24 \mathrm{f}$ & $1.53 \mathrm{ef}$ & $0.94 \mathrm{f}$ \\
\hline
\end{tabular}

Means followed by a common letter across water management, fertilizer and spacing are not significantly different at $5 \% \mathrm{HSD}$

Generally, plants at closer spacing had higher leaf area index compared to plants at wider spacing. This could be attributed to the higher number of plants at closer spacing which more than compensated for the lower leaf area per plant. Leaf area index increased with time from 45 to 73 DAT and decline afterwards at 86 DAT (Figure 3). 
Morphological and physiological performance of PSB Rc18 lowland rice

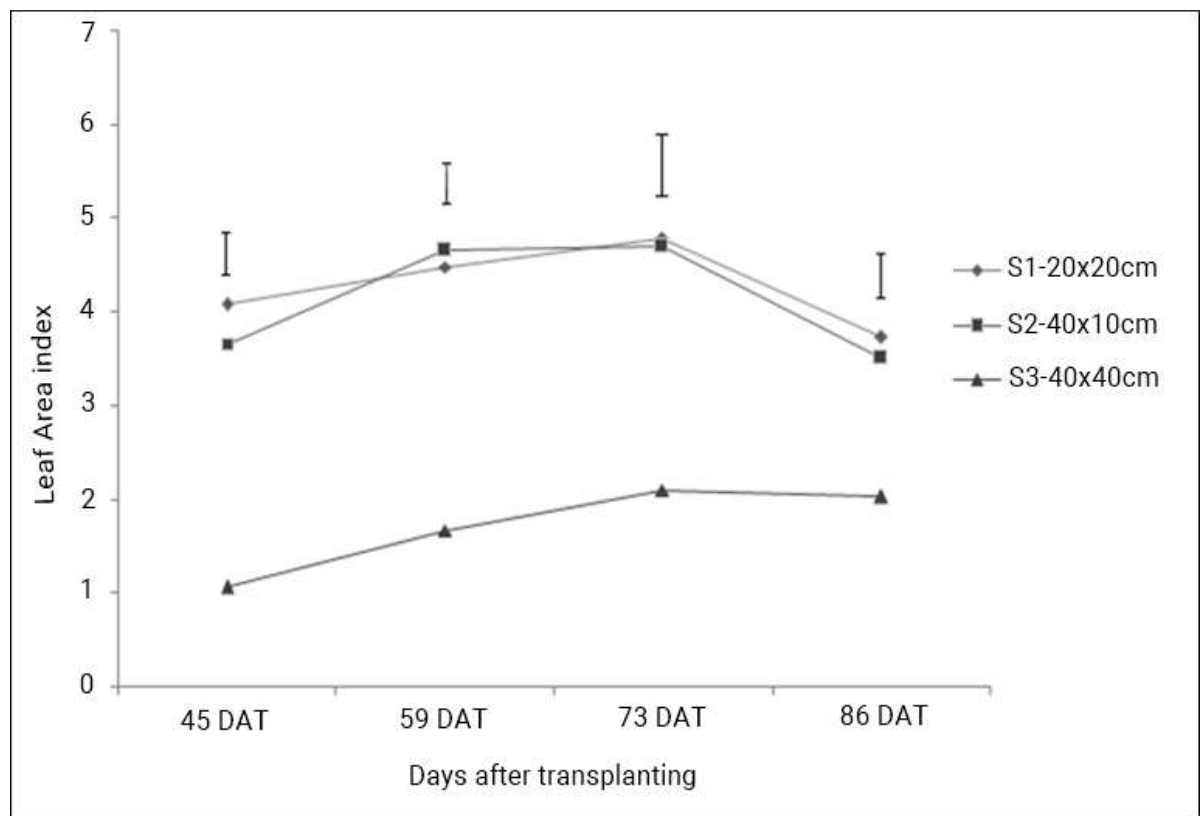

Figure 3. Leaf area index at various stages of growth as affected by spacing (WS 07-08). Vertical bars indicate HSD at $5 \%$ level

\section{Harvest Index}

Harvest index was significantly affected by water management, fertilizer and spacing during the wet and dry seasons. Plants under no flooding condition had significantly higher harvest index than those under continuous flooding. Harvest indexes of plants applied with organic fertilizers (goat manure \& compost mixture) were statistically at par with those applied with inorganic fertilizer. Application of fertilizers generally increased $\mathrm{HI}$, indicating efficient translocation of assimilates for grain production. Unfertilized plants gave the lowest harvest index (Table 15). Plants at closer spacing $(20 \mathrm{~cm} \times 20 \mathrm{~cm} \& 40 \mathrm{~cm} \times 10 \mathrm{~cm})$ had significantly higher $\mathrm{HI}$ compared to those at wider spacing $(40 \mathrm{~cm} \times 40 \mathrm{~cm})$.

Table 15. Harvest index of lowland rice as affected by water management, fertilizer and plant spacing at different cropping periods (WS 07-08, DS 2008)

\begin{tabular}{lcc}
\hline \multicolumn{1}{c}{ Treatments } & Wet Season & Dry Season \\
\hline Water Management & & \\
Continuous Flooding (WM1) & $0.37 \mathrm{~b}$ & $0.37 \mathrm{~b}$ \\
No Flooding (WM2) & $0.41 \mathrm{a}$ & $0.40 \mathrm{a}$ \\
HSD 0.05 & 0.02 & 0.03 \\
Fertilizer & & \\
Goat Manure (F1) & $0.41 \mathrm{a}$ & $0.41 \mathrm{a}$ \\
Compost mixture (F2) & $0.40 \mathrm{a}$ & $0.39 \mathrm{a}$ \\
Inorganic fertilizer (F3) & $0.42 \mathrm{a}$ & $0.42 \mathrm{a}$ \\
Control (F4) & $0.32 \mathrm{~b}$ & $0.32 \mathrm{~b}$ \\
HSD 0.05 & 0.04 & 0.05 \\
\hline
\end{tabular}


Table 15 continued

\begin{tabular}{ccc}
\hline \multicolumn{1}{c}{ Treatments } & Wet Season & Dry Season \\
\hline Spacing & & \\
$20 \times 20 \mathrm{~cm}(\mathrm{~S} 1)$ & $0.42 \mathrm{a}$ & $0.41 \mathrm{a}$ \\
$40 \times 10 \mathrm{~cm}(\mathrm{~S} 2)$ & $0.42 \mathrm{a}$ & $0.40 \mathrm{a}$ \\
$40 \times 40 \mathrm{~cm}(\mathrm{~S} 3)$ & $0.32 \mathrm{~b}$ & $0.33 \mathrm{~b}$ \\
HSD 0.05 & 0.03 & 0.04
\end{tabular}

Means within a column followed by a common letter are not significantly different at $5 \% \mathrm{HSD}$

Increase in $\mathrm{HI}$ in all treatments was closely related to increments in grain yield. Harvest index is a measure of the partitioning coefficient of photosynthate between the grains and the vegetative plant. Improvement in harvest index emphasizes the importance of carbon allocation in grain production. It is an indicator of how efficient the crop is at producing grain. A high harvest index is desired for rice (Fageria et al 2003). Published $\mathrm{HI}$ values for rice usually range from 0.35 to 0.55 (Counce et al 1992, Wilson et al 1994). Harvest index in this experiment ranged from 0.32 to 0.42 , which is very close to those reported in literature and higher than those reported earlier for hybrid rice $(0.29-0.37)$ by Peng et al (2003).

\section{Yield and Yield Components}

\section{Productive tillers per $\mathrm{m}^{-2}$}

More productive tillers were observed in plants grown under no flooding condition compared to those under continuous flooding, in both wet and dry seasons (Table 15). Vijayakamur at al (2006) and Uphoff (2001) stated that an increase in tiller production under no flooding is due to more availability of both oxygen and nitrogen in the root zone. Plants applied with organic and inorganic fertilizers produced higher number of productive tillers than the unfertilized plants (Table 15). Closer spacing of $20 \mathrm{~cm} \times 20 \mathrm{~cm}$ and $40 \mathrm{~cm} \times 10 \mathrm{~cm}$ gave higher productive tillers $\mathrm{m}^{-2}$ than wider spacing in both seasons (Table 16) due to more plant population per unit area under close spacing, while the decrease in productive tiller $\mathrm{m}^{-2}$ at wider spacing $(40 \mathrm{~cm} \times 40 \mathrm{~cm})$ was due to substantial decrease in population.

Table 16. Number of productive tillers $\mathrm{m}^{-2}$ as affected by water management, fertilizer and plant spacing in during (07-08) and dry (2008) seasons

\begin{tabular}{lcc}
\hline Treatments & Wet Season & Dry Season \\
\hline Water Management & & \\
$\quad$ Continuous Flooding (WM1) & $258 \mathrm{~b}$ & $237 \mathrm{~b}$ \\
$\quad$ No Flooding (WM2) & $290 \mathrm{a}$ & $275 \mathrm{a}$ \\
HSD 0.05 & 22.52 & 18.73 \\
Fertilizer & & \\
$\quad$ Goat Manure (F1) & $298 \mathrm{a}$ & $277 \mathrm{a}$ \\
Compost mixture (F2) & $274 \mathrm{ab}$ & $272 \mathrm{ab}$ \\
Inorganic fertilizer (F3) & $289 \mathrm{a}$ & $240 \mathrm{bc}$ \\
Control (F4) & $234 \mathrm{~b}$ & $234 \mathrm{c}$ \\
HSD 0.05 & 42.36 & 35.22 \\
\hline
\end{tabular}


Morphological and physiological performance of PSB Rc18 lowland rice

Table 16 continued

\begin{tabular}{lcc}
\hline Treatments & Wet Season & Dry Season \\
\hline Spacing & $318 \mathrm{a}$ & $289 \mathrm{a}$ \\
$20 \times 20 \mathrm{~cm}(\mathrm{~S} 1)$ & $323 \mathrm{a}$ & $285 \mathrm{a}$ \\
$40 \times 10 \mathrm{~cm}(\mathrm{~S} 2)$ & $180 \mathrm{~b}$ & $194 \mathrm{~b}$ \\
$40 \times 40 \mathrm{~cm}(\mathrm{~S} 3)$ & 33.28 & 27.67 \\
\hline
\end{tabular}

Means within a column followed by a common letter are not significantly different at $5 \%$ level, HSD

\section{Number of Filled Spikelets per Panicle}

No flooding gave higher number of filled spikelets panicle $e^{-1}$ than those grown under continuous flooding (Table 17). There was a significant difference in the number of filled spikelets panicle $e^{-1}$ among fertilizer treatments in the dry season only. Plants applied with inorganic fertilizer gave the highest filled spikelets but comparable to those applied with goat manure. The lowest number of filled spikelets was in the unfertilized plants; however, this was not significantly different to those applied with compost mixture.

Table 17. Number of filled spikelets panicle $e^{-1}$ of lowland rice as affected by water management, fertilizer and plant spacing during wet (07-08) and dry (2008) seasons

\begin{tabular}{lcc}
\hline \multicolumn{1}{c}{ Treatments } & Wet Season & Dry Season \\
\hline Water Management & $127 \mathrm{~b}$ & 135 \\
$\quad$ Continuous Flooding (WM1) & $141 \mathrm{a}$ & 133 \\
$\quad$ No Flooding (WM2) & 7.53 & $\mathrm{NS}$ \\
HSD 0.05 & & \\
Fertilizer & 132 & $134 \mathrm{ab}$ \\
$\quad$ Goat Manure (F1) & 129 & $132 \mathrm{~b}$ \\
Compost mixture (F2) & 143 & $144 \mathrm{a}$ \\
Inorganic fertilizer (F3) & 133 & $124 \mathrm{~b}$ \\
Control (F4) & $\mathrm{NS}$ & 11.66 \\
HSD 0.05 & & \\
Spacing & $127 \mathrm{~b}$ & $125 \mathrm{~b}$ \\
20x20cm (S1) & $126 \mathrm{~b}$ & $124 \mathrm{~b}$ \\
40x10cm (S2) & $150 \mathrm{a}$ & $152 \mathrm{a}$ \\
40x40cm (S3) & 11.13 & 9.16 \\
HSD 0.05 &
\end{tabular}

Means within a column followed by a common letter are not significantly different at $5 \%$ level, HSD.

In terms of spacing, higher number of filled spikelets per panicle was observed in plants grown at $40 \mathrm{~cm} \times 40 \mathrm{~cm}$ than at $20 \mathrm{~cm} \times 20 \mathrm{~cm}$ and $40 \mathrm{~cm} \times 10 \mathrm{~cm}$. This is because at wider spacing, there is less competition among plants for light and other growth factors, resulting in higher dry matter production; hence, higher filled spikelets panicle ${ }^{-1}$. 


\section{Weight of 1,000 grains $(g)$}

An important yield determining component is one thousand grain weight. It is a genetic character least influenced by environment (Ashraf et al 1999). Significant interaction between water management and fertilizer during the wet season was observed. Heavier weight of 1000 grains was recorded in plants applied with goat manure, under no flooding. Lighter weight was in the control plants grown under continuous flooding (Table 18).

Table 18. Thousand - grain weight $(\mathrm{g})$ of lowland rice as affected by water management $\mathrm{x}$ fertilizer interaction during the wet season (07-08)

\begin{tabular}{lcc}
\hline & $1000-$ Grain Weight $(\mathrm{g})$ & \\
\hline Goat manure & Continuous flooding & No flooding \\
Compost mixture & $27.36 \mathrm{ab}$ & $27.77 \mathrm{a}$ \\
Inorganic & $25.86 \mathrm{abc}$ & $26.11 \mathrm{abc}$ \\
Control & $25.46 \mathrm{abc}$ & $25.08 \mathrm{bc}$ \\
Means followed by a common letter across water management and fertilizer are not significantly different 5\% HSD
\end{tabular}

\section{Grain Yield $\left(\right.$ t ha $\left.^{-1}\right)$}

A three - way interaction among water management $x$ fertilizer $x$ spacing was significant (Table 19). The treatment combination of no flooding, application of goat manure and closer spacing of $20 \mathrm{~cm} \times 20 \mathrm{~cm}$ recorded the highest yield. This could be due to higher number of productive tillers under no flooding treatment (Table 15 ). In no flooding, there is abundant supply of oxygen to the root system which improves metabolism and provides more energy for the growing plant. More energy results in roots having more strength for developing and for active uptake of nutrients. Moreover, more tillers means greater number and density of roots and larger root system that supports more grain filling (Vallois et al 2000 \& Escasinas et al 2011).

Table 19. Grain yield $\left(\mathrm{t} \mathrm{ha}^{-1}\right)$ of lowland rice affected by the interaction among water management $\mathrm{x}$ fertilizer $x$ spacing interaction during the dry season (2008)

\begin{tabular}{|c|c|c|c|c|}
\hline \multicolumn{5}{|c|}{ Grain Yield $\left(\mathrm{t} \mathrm{ha}^{-1}\right)$} \\
\hline & Goat Manure & Compost Mixture & Inorganic & Control \\
\hline \multicolumn{5}{|l|}{ Continuous flooding } \\
\hline $20 \times 20 \mathrm{~cm}$ & $4.68 \mathrm{bcde}$ & 4.96abcde & 5.31abc & 3.71efgh \\
\hline $40 \times 10 \mathrm{~cm}$ & 4.99abcde & $4.18 \mathrm{cdefg}$ & $4.46 \mathrm{bcdef}$ & 4.55bcdef \\
\hline $40 \times 40 \mathrm{~cm}$ & $3.22 \mathrm{fgh}$ & 4.32bcdef & 3.77defgh & $2.64 \mathrm{~h}$ \\
\hline \multicolumn{5}{|l|}{ No Flooding } \\
\hline $20 \times 20 \mathrm{~cm}$ & $6.15 a$ & 5.19abc & $6.08 a$ & 3.82defgh \\
\hline $40 \times 10 \mathrm{~cm}$ & 5.12abcd & 5.09abcd & $5.58 \mathrm{ab}$ & 3.72efgh \\
\hline $40 \times 40 \mathrm{~cm}$ & $4.38 \mathrm{bcdef}$ & 4.36bcdef & $4.42 \mathrm{bcdef}$ & $2.84 \mathrm{gh}$ \\
\hline
\end{tabular}

Means followed by a common letter across water management, fertilizer and spacing are not significantly different at $5 \%, \mathrm{HSD}$

Application of composted goat manure contributed to high grain yield due to higher nutrient input, including the trace elements ( $\mathrm{Cu} \mathrm{\&} \mathrm{Zn)} \mathrm{of} \mathrm{goat} \mathrm{manure.} \mathrm{Goat}$ manure used in this study contained $3.187 \% \mathrm{~N}, 0.448 \% \mathrm{P}, 5.356 \mathrm{~K}, 28.50 \mathrm{ppm} \mathrm{Cu}$, $224.45 \mathrm{ppm} \mathrm{Zn}$ and $29.76 \%$ OM. The higher nutrient content of goat manure especially nitrogen, as well as the gradual but continuous release of nutrients, may 
Morphological and physiological performance of PSB Rc18 lowland rice

have contributed to higher grain yield. On the other hand, closer spacing had higher grain yield than wider pacing. This could be mainly attributed to the higher number of productive tillers $\mathrm{m}^{-2}$ due to relatively more number of plants per unit area.

\section{CONCLUSIONS}

Lowland rice grown either in continuous flooding and no flooding formed aerenchyma cells in roots with statistically similar cell size and number, confirming that aerenchyma forms speedily even in well-aerated, flooded and drained soils. Treatment combination of no flooding and wider spacing gave the highest root pulling resistance due to more tillers per hill, resulting in more roots anchoring the soil. No flooding resulted in reduced plant height a character that imparts resistance to lodging. The phyllochron and total leaf number on the main culm of PSB Rc18 were not affected by water management, spacing and nutrient management. However, PSB Rc18 at early growth stages tended to have longer phyllochron because of transplanting shock.

Application of inorganic fertilizer at the rate of $90-30-30 \mathrm{~kg} \mathrm{ha}^{-1} \mathrm{~N}_{2} \mathrm{P}_{2} \mathrm{O}_{5}$ and $\mathrm{K}_{2} \mathrm{O}$ at closer spacing of $20 \mathrm{~cm} \times 20 \mathrm{~cm}$ and $40 \mathrm{~cm} \times 10 \mathrm{~cm}$ under no flooding water management resulted in higher CGR, while planting at wider spacing at $40 \mathrm{~cm} \times 40 \mathrm{~cm}$ with goat manure as fertilizer under no flooding conditions gave higher NAR comparable to inorganic fertilizer. PSB Rc18 at closer spacing gave higher LAI due to higher number of plants per unit area. Closer spacing of $40 \mathrm{~cm} \times 10 \mathrm{~cm}$ and application of inorganic fertilizer under no flooding condition gave highest LAI during wet season; but during dry season, continuous flooding gave the highest LAI. Leaf area index of PSB Rc18 increased from 45 to 73 DAT and decline afterwards. The use of organic fertilizer, wider spacing and no flooding conditions gave the highest harvest index.

The use of composted goat manure and compost mixture as organic fertilizers in lowland rice could give yield comparable to inorganic fertilizer. Closer spacing of $20 \mathrm{~cm} \times 20 \mathrm{~cm}$ and $40 \mathrm{~cm} \times 10 \mathrm{~cm}$ give higher yield of PSB Rc 18 than $40 \mathrm{~cm} \times 40 \mathrm{~cm}$ due to more number of plants per unit area. The treatment combination of no flooding, application of composted goat manure and closer spacing of $20 \mathrm{~cm} \times 20 \mathrm{~cm}$ is the best combination comparable to plants applied with inorganic fertilizer at the rate of 90-30-30kg NPK ha-1.

\section{REFERENCES}

Association Tefy Saina and Laulanie HD. 1993. Technical Presentation of rice intensification of rice intensification based on Katayama's tillering model (Unpublished paper) translated from French, available from Cornell International Institute for Food, Agriculture and Development

Ashraf A, Khalid A \& Ali K. 1999. Effect of seedling age and density on growth and yield of rice in saline soil. Pakistan Journal of Biological Sciences 2(3):860862

Barber DA, Ebert M \& Evans NTS. 1962. The movement of ${ }^{15} \mathrm{O}_{2}$ through barley and rice plants. Journal of Experimental Botany 13:397-403

Bouman BAM, Lampayan RM \& Toung TP. 2007. Water management in irrigated rice: coping with water scarcity (pp54). Los Baños, Philippines: International Rice Research Institute 
Colmer TD. 2003. Long -distance transport of gases in plants: a perspective on internal aeration and radial oxygen loss from roots. Plant Cell \& Environment 26:17-36

Counce PA, Wells BR \& Gravois KA. 1992. Yield and harvest index responses to preflood nitrogen fertilization at low rice plant populations. Journal of Production Agriculture 5(4):492-497

Department of Agriculture. 2012. Food Staples Sufficiency Program 2011 - 2016. Quezon City, Philippines

Enquayehush M. 2004. The effects of seedling age, spacing and season on phyllochron, yield and yield components of rice using the principles of the system of rice intensification (MS thesis) (pp92). University of the Philippines Los Baños, Laguna, Philippines

Escasinas RO and OB Zamora. 2011. Agronomic response of lowland rice PSB Rc18 (Oryza sativa L.) to different water, spacing and nutrient management. Philippine Journal of Crop Science 35 (2):37-46

Evans D. 2003. Aerenchyma formation. New Phytologist Trust 161:35-49

Fageria NK and Baligar VC. 2003. Lowland rice response to nitrogen fertilization. Communications in Soil Science and Plant Analysis 32(9-10):1405-1429

George T, Magbanua R, Roder W, Van Keer K, TrebuiL G \& Reoma V. 2001. Upland rice response to phosphorus fertilization in Asia. Agronomy Journal 93(6):1362 $-1370$

Gomez KA.1972. Technique for field experiments with rice. IRRI. Los Baños, Philippines

Haun JR. 1973. Visual quantification of wheat development. Agronomy Journal 65 (1):116-119

International Rice Research Institute (IRRI). 1995. Mechanisms of Adaptation to waterlogging and submergence. IRRI. Los Baños, Philippines

Jackson MB, Fenning TM \& Jenkins W. 1985. Aerenchyma (gas-space) formation in adventitious roots of rice (Oryza sativa L.) is not controlled by ethylene or small partial pressure of oxygen. Journal of Experimental Botany 36(10):1566-1572

Justin S and Armstrong W. 1991. Evidence for the involvement of ethane in aerenchyma formation in adventitious roots of rice (Oryza sativa). New Physiologist 118(1):49-62

Landon JR. 1991. Booker tropical soil manual: A handbook for soil survey and agricultural land evaluation in the tropics and subtropics. Paperback edition. Booker Agricultural International Ltd., London

Nemoto K, Morita S \& Baba T. 1995. Shoot and root development in rice related to the phyllochron. Crop Science 35(1):24-29

O'Toole JC and Soemartono C. 1981. Evaluation of a simple technique for characterizing rice root systems in relation to drought resistance. Euphytica 30(2):283-290

Philippine Council for Agriculture, Forestry and Natural Resources Research and Development (PCAARRD). 1986. Environmental adaptation of crops. Book Series No. 37 (pp289). PCARRD Foundation Inc. Los Banos, Laguna, Philippines

Philippine Council for Agriculture and Resources Research (PCARR). 1980. Standard Methods of Analysis for Soil, Plant Tissue, Water and Fertilizer (pp194). Philippine Council For Agricultural Resources and Research. Los Banos, Laguna 
Morphological and physiological performance of PSB Rc18 lowland rice

Peng SJ, Yang RC, Laza A, Sanico L, Visperas RM \& Sonn TT. 2003. Physiological bases of heterosis and crop management strategies for hybrid rice in the tropics. In Virmani SS, Mao CX \& Hardy B (eds) Hybrid rice for food security, poverty alleviation, and environmental protection (pp153-172). Proceedings of the 4th International Symposium on Hybrid Rice. Hanoi, Vietnam, 14-17 May 2002. Los Baños (Philippines): International Rice Research Institute

Puard M, Couchat P \& Lasceve G. 1986. Importance de l'oxygenation des raciness du riz (Oryza sativa) en culture enondee. L'Agronomie Tropicale 44(2):119-123

Shannon RD, White JR, Lawson JE \& Gilmour BS. 1996. Methane efflux from emergent vegetation in peat lands. Journal of Ecology 84(2):239-246

Uphoff N. 2001. Scientific issues raised by the system of rice intensification. A less water cultivation system. In Hengsdijk $\mathrm{H}$ and Bindraban $\mathrm{P}$ (eds) Water saving rice production systems (pp69-82). Proceedings of an International Workshop on Water Saving Rice Production Systems. April 2-4, 2001. Nanjing University, China

Vallois P, Uphoff N \& Collick A. 2000. Malagasy System of Rice Intensification. Early Rice Planting System

Vijayakamur M, Ramesh S, Prabhakaran NK, Subbian P \& Chandrasekaran B. 2006. Influence of System of Rice Intensification (SRI) on Growth Characters, Days to Flowering, Growth Analysis and Labour Productivity of Rice. Asian Journal of Plant Sciences 5(6):984-989

Wilhelm WW and McMaster GS. 1995. Importance of the phyllochron in studying development and growth in grasses. Crop Science 35(1):1-3

Wilson CE JR, Bollich PK \& Norman RJ. 1994. Nitrogen application timing effects on nitrogen efficiency of dry-seeded rice. Soil Science Society of America Journal 62(4):959-964

Yoshida S, Forno DA, Cook JH \& Gomez KA. 1976. Laboratory Manual for Physiological Studies in Rice (3rd edn). IRRI. Los Baños, Philippines

Yoshida S. 1977. Rice. In Alvim PT and Kozlowski TT (eds) Ecophysiology of Tropical Crops. Academic Press, New York 